\title{
Batch and Flow-Injection Spectrophotometric Determination of Thymol Using Procaine Hydrochloride as a New Chromogenic Reagent
}

\author{
Mouyed Q. Al-Abachi*
}

Hind S. Al-Ward*

Received 31, March, 2011

Accepted 10, July, 2011

\begin{abstract}
:
New, simple and sensitive batch and Flow-injecton spectrophotometric methods for the determination of Thymol in pure form and in mouth wash preparations have been proposed in this study. These methods were based on a diazotization and coupling reaction between Thymol and diazotized procaine $\mathrm{HCl}$ in alkaline medium to form an intense orange-red water-soluble dye that is stable and has a maximum absorption at $474 \mathrm{~nm}$. A graphs of absorbance versus concentration show that Beer's law is obeyed over the concentration range of 0.4-4.8 and 4-80 $\mu \mathrm{g} . \mathrm{ml}^{-1}$ of Thymol, with detection limits of 0.072 and $1.807 \mu \mathrm{g} \cdot \mathrm{ml}^{-1}$ of Thymol for batch and FIA methods respectively. The FIA procedure sample throughput was $80 \mathrm{~h}^{-}$ 1. All different chemical and physical experimental parameters that affecting on the development and stability of the colored product were carefully studied and the proposed methods were successfully applied to the determination of Thymol in mouth wash preparations.
\end{abstract}

Key words: Thymol, Spectrophotometric determination, Procaine hydrochloride, Diazotization and coupling, Flow injection.

\section{Introduction:}

Thymol is a 5-methyl-2-(methylethyl) phenol, $\mathrm{C}_{10} \mathrm{H}_{14} \mathrm{O}$, whereas its chemical structure is [1]:<smiles>Cc1ccc(C(C)C)c(O)c1</smiles>

Thymol resembles phenol in its action, but owing to its insolubility in the fluids of the body it is absorbed much more slowly; it is also less irritant to wounds, while its germicidal action is greater than that of phenol, though less than that of naphthol. In alcoholic solution it penetrates, the skin and produces local anaesthesia. It is used as an antiseptic lotion and mouth wash (1 in 1000), or as Liquor
Thymolis Compositus; as a paint in ringworm (1 in 10 of alcohol, or alcohol and ether); and as an ointment (1 in 24 of soft paraffin, the Thymol being dissolved with the aid of heat) in eczema, psoriasis, broken chilblains, parasitic skin affections, and burns. An ointment half this strength, perfumed with oil of lavender, is used to keep off gnats and mosquitoes. Thymol in oily solution ( 1 or 2 per cent.) is applied to the respiratory passages by means of a spray in nasal catarrh and its also used to medicate absorbent gauze and wool for use as surgical dressings [2]. A number of analytical methods have been reported for the determination of Thymol, these included high pressure liquid chromatography [3-5], liquid chromatography with electrochemical

*Department of Chemistry-College of Science-University of Baghdad-Baghdad-Iraq 
detection [6], gas chromatography [710], differential-pulse voltammetry [11], ultraviolet spectrometry [12] and colorimetric analysis [13].

The present study describes the development of bacth and FIA methods based on diazotiazation and coupling reaction between Thymol and diazotized procaine hydrochloride as a new chromogenic reagent (procaine $\mathrm{HCl}$ is an amino drug which used as a local anesthetic drug) in alkaline medium. The orange-red product was spectrophotometrically measured at $474 \mathrm{~nm}$. The analytical procedure is simple, fast, accurate and the using reagent was non poisonous. It has been satisfactorily applied for the determination of Thymol in pure and mouth wash preparations, the reaction can be carried out in batch and FIA and the two approaches are compared.

\section{Materials and Methods: Apparatus}

-All spectral and absorbance measurements were carried out on a Shimadzu UV-Visble-260 digital double-beam recording spectrophotometer (Tokyo-Japan), using 1-cm quartz cells. A quartz flow cell with $50 \mu 1$ internal volume and 1 $\mathrm{cm}$ bath length was used for the absorbance measurements. A two channel manifold (Figure 4) was employed for the FIA spectrophotometer determination of Thymol. A peristaltic pump (Ismatec, Labortechnik-Analytic, CH-8152, Glatbrugg-Zurich, Switzerland, six channels) was used to transport the reagents solutions, Injection valve (Rheodyne, Altex 210, Supelco-USA) which was employed to provide appropriate injection volumes of standard solutions and samples. Flexible vinyl tubing of $0.5 \mathrm{~mm}$ internal diameter was used for the peristaltic pump. Reaction coil (RC) was of Teflon with internal diameter of
$0.5 \mathrm{~mm}$. In (Figure 1) the diazotized procaine $\mathrm{HCl}$ (R1) stream have been combined with injected sample and they merged with $\mathrm{NaOH}$ (R2) stream at T-link then mixed in reaction coil (RC) with length of $100 \mathrm{~cm}$, injection loop of $(150 \mu \mathrm{l})$, total flow rate of 2.4 $\mathrm{ml} / \mathrm{min}$, the absorbance has been measured at $474 \mathrm{~nm}$, and at room temperature $\left(10-15 \mathrm{C}^{\circ}\right)$.

\section{Reagents and materials}

Analytical reagents grade chemicals and distilled water were used thoroughly.

Thymol stock solution $\left(1000 \mu \mathrm{g} \cdot \mathrm{ml}^{-1}\right)$ : a 0.10000 gm amount of pure Thymol (BDH) was dissolved in $5 \mathrm{ml}$ of ethanol then complete to $100 \mathrm{ml}$ in a volumetric flask with distilled water. Thymol working solution $\left(100 \mu \mathrm{g} \cdot \mathrm{ml}^{-1}\right)$, was prepared by dilution of $10 \mathrm{ml}$ of the stock solution to $100 \mathrm{ml}$ volumetric flask with distilled water.

Diazotized Procaine HCl $\left(1 \times 10^{-2} \mathrm{M}\right)$ reagent solution: prepared by dissolving $0.2728 \mathrm{gm}$ of pure procaine $\mathrm{HCl}$ (SDI) in amount of distilled water then added $6 \mathrm{ml}$ of $0.8 \mathrm{M} \mathrm{HCl}(\mathrm{BDH})$ shake well and followed by $0.0690 \mathrm{gm}$ of sodium nitrate (BDH) shake thoroughly and after 5 min made the volume up to $100 \mathrm{ml}$ with distilled water to obtained $\left(1 \times 10^{-2} \mathrm{M}\right)$ for both reagent and $\mathrm{NaNO}_{2}$, the working solution $(1 \mathrm{mM})$ was prepared by dilution of $10 \mathrm{ml}$ of the stock solution to $100 \mathrm{ml}$ volumetric flask with distilled water.

Hydrochloric acid (BDH) (0.8M): prepared by diluting suitable amount of concentrated hydrochloric acid to 100 $\mathrm{ml}$ with distilled water.

Sodium hydroxide (BDH) (4M) stock solution: prepared by dissolving 16 gm of $\mathrm{NaOH}$ in $100 \mathrm{ml}$ volumetric flask and complete the volume to the mark with distilled water.

More dilute solutions were prepared daily by suitable dilution with distilled water. 


\section{Procedure for Mouth wash:}

Two types of mouth wash were analyzed by the developed methods, these include:-

1-Breath Rx (mouth rinse-anti bacterial-USA),this type of mouth wash containing $0.060 \%$ Thymol, transfer $20 \mathrm{ml}$ of the mouth wash preparation to a $50 \mathrm{ml}$ volumetric flask, add $5 \mathrm{ml}$ of ethanol and dilute to the mark with distilled water. The concentration of this solution was (240 $\left.\mu \mathrm{g} \cdot \mathrm{ml}^{-1}\right)$ stock solution. Working solution of $100 \mu \mathrm{g} \cdot \mathrm{ml}^{-1}$ was prepared by simple dilution of the stock solution.

2-Listerine-antiseptic(USA):

containing $0.063 \%$ Thymol, transfer $20 \mathrm{ml}$ of the mouth wash preparation to a $50 \mathrm{ml}$ volumetric flask then add $5 \mathrm{ml}$ of ethanol and dilute to the mark with distilled water. The concentration of this prepared solution was $\left(252 \mu \mathrm{g} \cdot \mathrm{ml}^{-1}\right)$ stock solution, $\left(100 \mu \mathrm{g} \cdot \mathrm{ml}^{-1}\right)$ solution was prepared by simple dilution of the stock solution.

\section{Procedures:}

\section{General batch procedure}

An aliquot of sample containing 10-120 $\mu \mathrm{g}$ of pure Thymol was transfer into a series of $25 \mathrm{ml}$ standard flask. Add $1 \mathrm{ml}$ of diazotized procaine $\mathrm{HCl}$ and $0.7 \mathrm{ml}$ of sodium hydroxide $(0.5 \mathrm{M})$, the contents of the flasks were diluted to the mark with distilled water, mixed well and left for $15 \mathrm{~min}$ at room temperature, the absorbance of the orange-red dye formed was measured at $474 \mathrm{~nm}$ against a reagent blank containing all materials except Thymol. A calibration graph was drawn and the regression equation was calculated, for the optimization of conditions and in all subsequent experiments, a solution of $100 \mu \mathrm{g}$ was used in a final volume of $25 \mathrm{ml}$.

\section{General FIA procedure}

A Thymol concentration in the range of 4-80 $\mu \mathrm{g} \cdot \mathrm{ml}^{-1}$ were prepared from the working solution of $100 \mu \mathrm{g} \cdot \mathrm{ml}^{-1}$. A $150 \mu \mathrm{l}$ portion of Thymol was injected into the stream of the diazotized procaine $\mathrm{HCl}$ then the mixture combine with $(0.5 \mathrm{M}) \mathrm{NaOH}$ at T-link with a total flow rate of 2.4

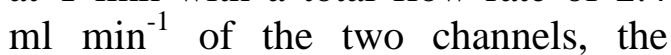
resulting absorbance of the orange-red product was measured at $474 \mathrm{~nm}$ and a calibration graph was constructed. Optimization of conditions were carried out on $10 \mu \mathrm{g} \cdot \mathrm{ml}^{-1}$ of Thymol.

\section{Results and discussion:}

The factors affecting on the sensitivity and stability of the colored product resulting from the diazonium reaction between Thymol and diazotized procaine $\mathrm{HCl}$ in alkaline medium were carefully studied. A typical spectrum for the azo dye formed was measured versus reagent blank which has negligible absorbance at $\lambda \max 474 \mathrm{~nm}$ (Figure 1).

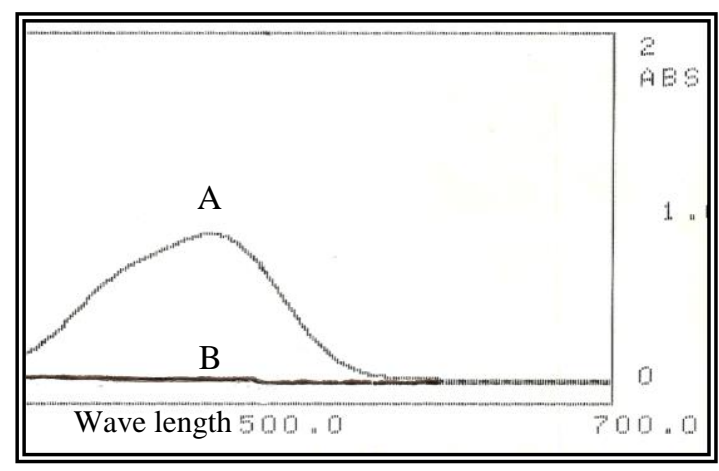

Fig. 1:Absorption spectra of the azo dye against reagent blank (A) and blank against distilled water (B).

Batch spectrophotometric determination The experimental conditions for the determination of Thymol were established. Diazonium reaction occurred in an acidic medium [14] and hydrochloric acid of concentration of $0.8 \mathrm{M}$ was selected [15], the effect of different volumes of $0.8 \mathrm{M}$ of $\mathrm{HCl}$ were studied and $6 \mathrm{ml}$ volume seems to 
be the optimum for an intense azo dye absorbance. A 1:1 mole ratio of procaine $\mathrm{HCl}$ to sodium nitrite of $(1 \mathrm{mM})$ was used in order to prevent the effect of excess of sodium nitrite. The effect of diazonium reagent $(1 \mathrm{mM})$ volume $(0.1-5 \mathrm{ml})$ on the intensity of the absorbance, has been studied and $1 \mathrm{ml}$ was found to be optimum. The absorbance of the dye formed became more intense and stable in alkaline medium, therefore, the effect of different alkaline solutions on the colored product were studied such as sodium hydroxide, ammonium hydroxide, potassium hydroxide, sodium acetate and sodium carbonate. Maximum sensitivity and stability were obtained only when the reaction was carried out in the presence of sodium hydroxide solution. The effect of different concentrations of $\mathrm{NaOH}$ were studied, $(0.1-4 \mathrm{M})$ and $0.5 \mathrm{M}$ seems to be optimum. The effect of $(0.5 \mathrm{M}) \mathrm{NaOH}$ volumes were also studied from 0.1 to $3 \mathrm{ml}$ and $0.7 \mathrm{ml}$ was found optimum.

Experimental results revealed that the colour intensity reaches a maximum after Thymol solution had been reacted with diazotized procaine $\mathrm{HCl}$ in alkaline medium for $10 \mathrm{~min}$, therefore, a 15 min development time was suggested as the optimum reaction time and remain stable for $120 \mathrm{~min}$. The order of addition of the reagents is an essential part of the experiment, it was found that the order of addition of the reagent cited under general procedure gave a maximum color intensity and the minimum absorbance of the blank and was used in all subsequent experiments. The effect of temperature on the colour intensity of the dye was studied. In practice, a higher absorbance was obtained when the reaction was developed at room temperature (10-15 $\left.\mathrm{C}^{\circ}\right)$ and when the calibrated flasks were placed in an ice bath $\left(0-5 C^{0}\right)$ or in a water bath $\left(60 C^{0}\right)$ a decreased in absorbance were observed.

The stoicheiometry of the reaction between Thymol and diazotized procaine $\mathrm{HCl}$ was investigated using both continuous variation and molar ratio methods respectively, The results obtained (figure $2 \& 3)$ show that a (1:1) azo dye was formed between Thymol and diazotized procaine $\mathrm{HCl}$ [16].

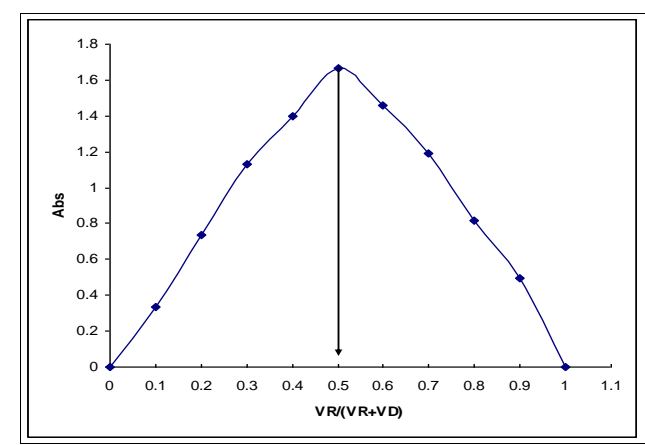

Fig.2 : Continuous variation plot

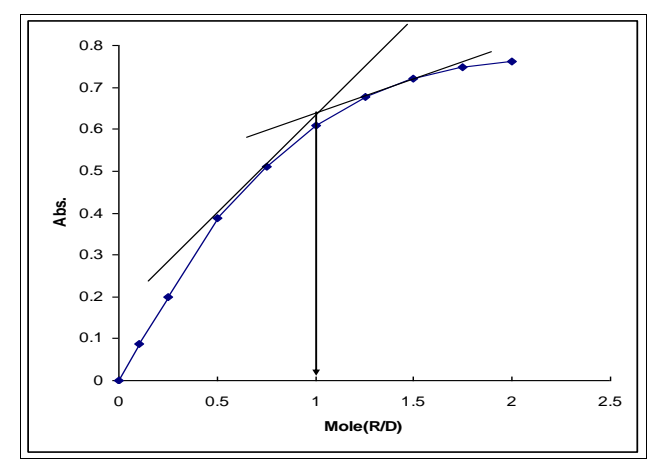

Fig. 3: Mole ratio plot

A reaction subsequent based on the above results is shown in Scheme (1). 


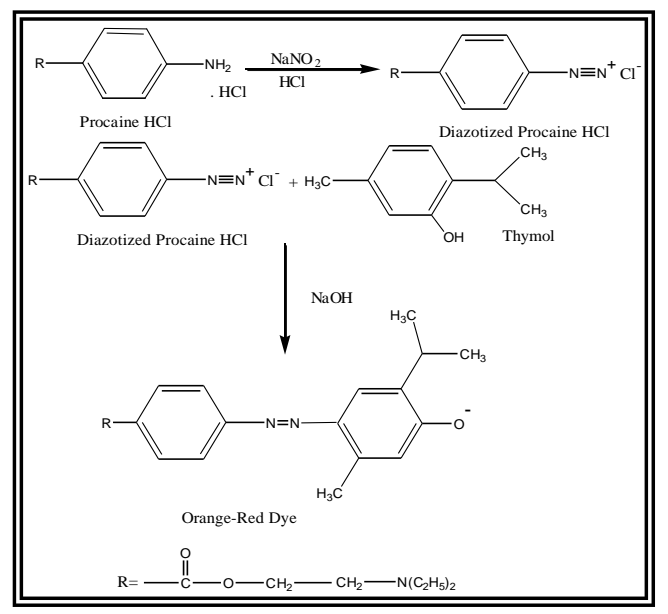

Scheme (1): reaction sequence

The product formed was soluble in water. The apparent stability constant was calculated by comparing the absorbance of a solution containing stiochiometric amount of Thymol (6.65 x $\left.10^{-4} \mathrm{M}\right)\left(\mathrm{A}_{\mathrm{S}}\right)$ with that of a solution containing a five - fold excess of diazotized procaine $\mathrm{HCl}$ reagent $\left(\mathrm{A}_{\mathrm{m}}\right)$ and according to analytical procedure. The average stability constant $(\mathrm{K})=$ $4.513 \times 10^{5} \mathrm{~L}^{\mathrm{mol}}{ }^{-1}$, where is $[\mathrm{K}=(1-\alpha) /$ $\left.\alpha^{2} \mathrm{C}\right]$ and $\alpha=\mathrm{A}_{\mathrm{m}}-\mathrm{A}_{\mathrm{s}} / \mathrm{A}_{\mathrm{m}}[16]$.

The regression equation obtained, and the analytical features of the procedure are summarized in (Table 1). It also summarized the main performance of the flow procedure developed for Thymol determination in order to make an effective comparison between the two approach.

Table 1: Analytical characteristics of the procedure developed for the determination of Thymol

\begin{tabular}{|c|c|c|}
\hline Parameters & $\begin{array}{c}\text { Batch } \\
\text { procedure }\end{array}$ & FIA procedure \\
\hline Regression equation & $\begin{array}{c}\mathrm{Y}=0.2076 \mathrm{x}- \\
0.0084\end{array}$ & $\begin{array}{c}\mathrm{Y}=0.0249 \mathrm{x}- \\
0.0174\end{array}$ \\
\hline Linear range $\left(\mu \mathrm{g} \mathrm{ml}^{-1}\right)$ & $0.4-4.8$ & $4-80$ \\
\hline $\begin{array}{c}\text { Correlation } \\
\text { coefficient, } \mathrm{r}^{2}\end{array}$ & 0.9994 & 0.9989 \\
\hline $\begin{array}{c}\text { Limit of detection } \\
\left(\mu \mathrm{g} \mathrm{ml}^{-1}\right)\end{array}$ & 0.072 & 1.807 \\
\hline $\begin{array}{c}\text { Relative standard } \\
\text { deviation (RSD) \% }\end{array}$ & 0.540 & 0.697 \\
\hline Average of recovery $\%$ & 100.66 & 99.93 \\
\hline $\begin{array}{c}\text { Molar absorptivity } \\
\left(1 \mathrm{~mol}^{-1} \mathrm{~cm}^{-1}\right)\end{array}$ & $2.98 \times 10^{4}$ & $3.73 \times 10^{4}$ \\
\hline $\begin{array}{l}\text { Sandell's sensitivity } \\
\left(\mu \mathrm{g} \mathrm{cm}^{-2}\right)\end{array}$ & 0.0547 & 0.0401 \\
\hline $\begin{array}{l}\text { Through-put sample } \\
\left(\mathrm{hr}^{-1}\right)\end{array}$ & 4 & 80 \\
\hline
\end{tabular}

\section{FIA-spectrophotometric determination}

The batch method for the determination of Thymol was adopted as a basis to develop FIA procedure. The manifold used for the determination of Thymol was designed to provide different reaction conditions for magnifying the absorbance signal generated by the reaction of Thymol with diazotized procaine $\mathrm{HCl}$ in sodium hydroxide medium. Maximum absorbance intensity was obtained when the sample was injected into a stream of diazotized reagent and then mixed with sodium hydroxide [17], as given in (Figure 4). The influence of different chemical and physical FIA parameters on the absorbance intensity of the colored product has been optimized as follows:

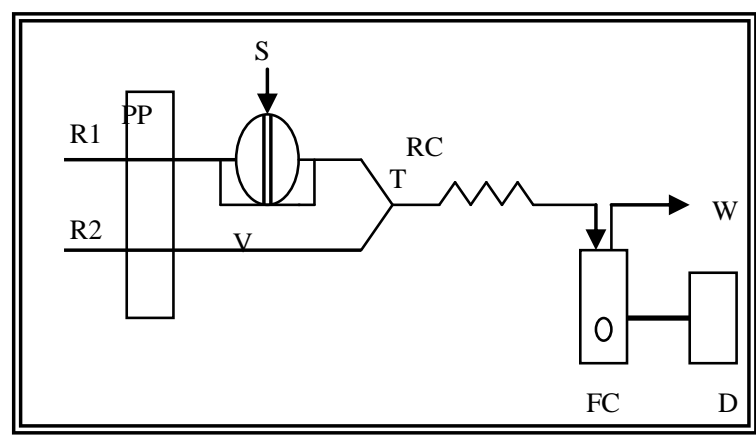

Fig. 4: A schematic diagram of FIA manifold

Where: R1 and R2, solutions of diazotized reagent and base respectively; $P P$ =peristaltic pump; $S=$ injection sample; $I V=$ injection valve; $T=T$-link; $R C=$ reaction coil; $F C=$ flow cell; $D=$ detector; $W=$ waste.

\section{Optimization of chemical parameters}

The effects of various concentrations of diazotized procaine $\mathrm{HCl}$ have been investigated. A concentration of $1 \mathrm{mM}$ (procaine $\mathrm{HCl}$ and $\mathrm{NaNO}_{2}$ with $3 \mathrm{ml}(0.8 \mathrm{M}) \mathrm{HCl}$ in $100 \mathrm{ml}$ distilled water), gave the highest absorbance and was chosen for further use. The results obtained are shown in (Figure 5) 


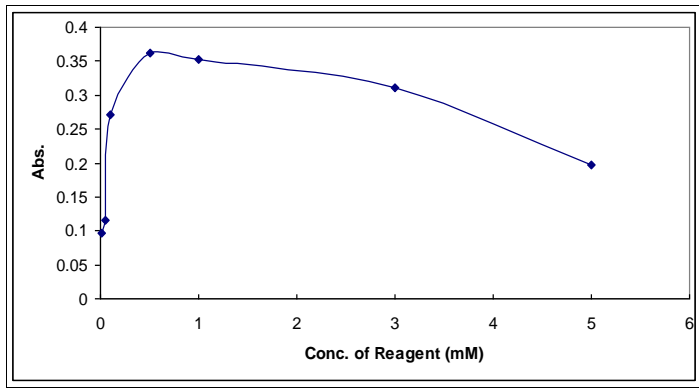

Fig. 5: Effect of the concentration of diazotized reagent in $(\mathrm{mM})$

It was observed that the reaction between Thymol and diazotized procaine $\mathrm{HCl}$ depends on alkaline medium, the effect of different concentration of sodium hydroxide was studied and $0.05 \mathrm{M}$ was found to be the optimum as shown in (Figure 6).

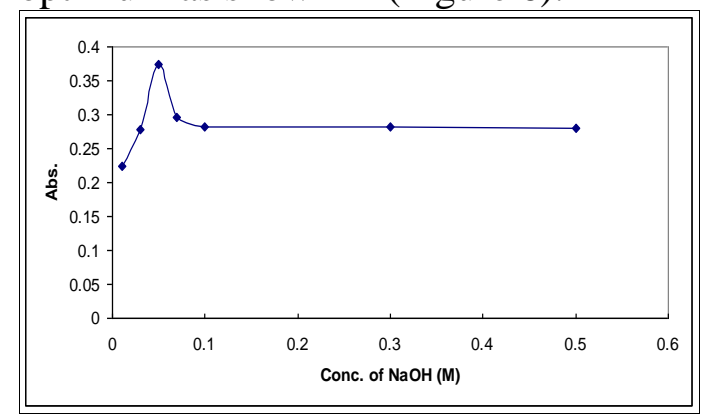

Fig. 6: Effect of the concentration of sodium hydroxide in $(M)$

\section{Optimization of manifold parameters}

The variables studied under the optimized reagent concentrations were the flow rate, the injection sample volume and the reaction coil length.

The effect of total flow rate on the sensitivity of the colored reaction product was investigated in the range of $0.25-2.50 \mathrm{ml} \mathrm{m^{-1 }}$. the results obtained showed that a total flow rate of $2.4 \mathrm{ml} \mathrm{min}^{-1}$, $\left(1.2 \mathrm{ml} \mathrm{min}{ }^{-1}\right.$ in each line) gave the highest absorbance as shown in (Figure 7), and were used in all subsequent experiments.

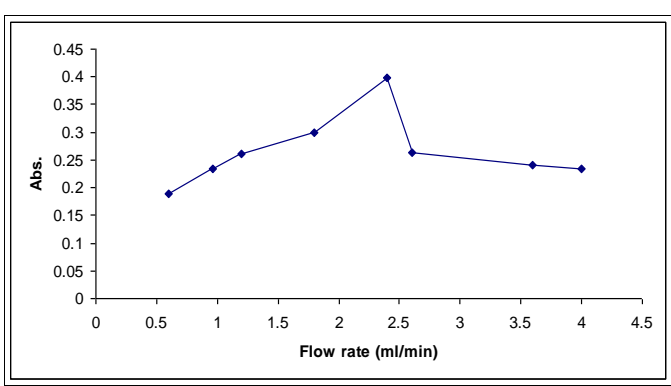

Fig. 7: Effect of the total flow rate (ml/min)

The volume of the injection sample was varied between $50-250 \mu 1$ using different length of sample loop. The results (Figure 8) obtained showed that injected sample of $150 \mu$ l gave the best absorbance.

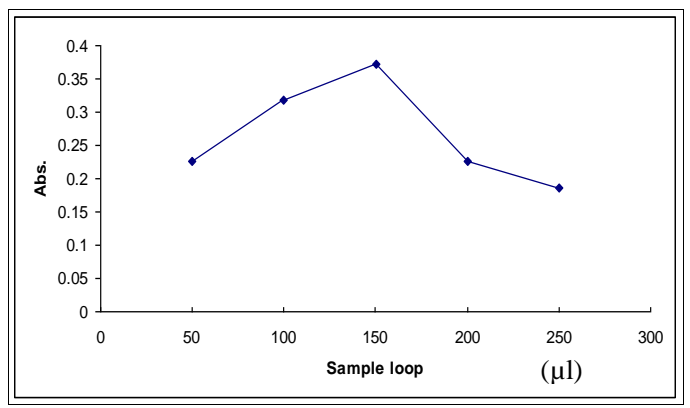

Fig. 8: Effect of the injection $\operatorname{loop}(\mu \mathrm{l})$

The coil length is an essential parameter that affects on the sensitivity of the colored reaction product and was investigated in the range of $25-250 \mathrm{~cm}$. The results obtained showed that a coil length of $100 \mathrm{~cm}$ gave the highest absorbance as shown in (Figure 9) and was used in all subsequent experiments.

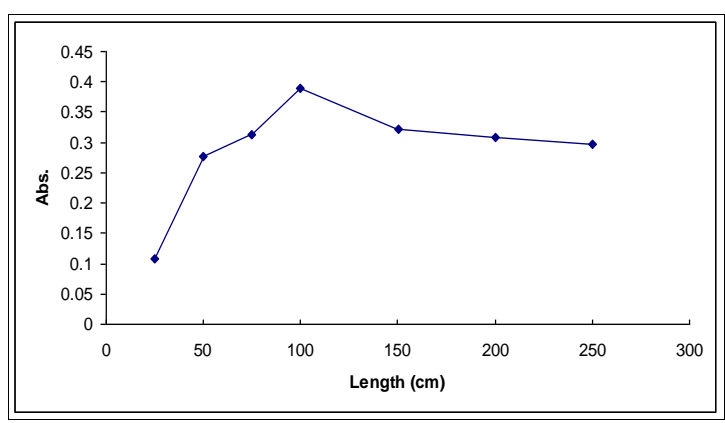

Fig.9: Effect of the length of the reaction coil in $(\mathrm{cm})$

The reaction time is also an important parameter that affects on the sample throughput and was 
investigated by calculating the interval time between the sample injection and the appearance of the end of the signal. The reaction time of each sample was $45 \mathrm{sec}$, therefore the sample through put was 80 samples per hour.

The dispersion of the colored product was studied by using optimum reaction conditions and the FIA manifold in Figure 4, and found to be 1.611 which indicate a limited dispersion FIA (short reactors tubes, small tube id's, and large sample volumes) [18].

\section{Analytical characteristics}

Analytical characteristics such as linear range, detection range, correlation coefficient and relative standard deviation (RSD) of each method were determined under the optimized conditions as shown in (Table 1). In comparison of the batch with the FIA procedure, the later is more convenient than the former method because of its speed (sample through-put of 80 injection $\mathrm{h}^{-1}$ ), wider linear range of calibration graph, and good recovery were obtained.

\section{Analysis of mouth wash samples}

The suggested methods were applied to the quantitative determination of Thymol in mouth wash formulation. Two types of mouth wash preparations containing Thymol were analyzed and they gave a good accuracy and precision as shown in (Table 2). The proposed method were compared successfully with the official method [19].

Table 2: Application of the proposed and official methods for the determination of mouth wash containing Thymol

\begin{tabular}{|c|c|c|c|c|c|}
\hline \multirow{2}{*}{$\begin{array}{c}\text { Mouth } \\
\text { wash } \\
\text { sampls }\end{array}$} & \multicolumn{4}{|c|}{ Proposed method } & \multirow{2}{*}{$\begin{array}{c}\text { Official } \\
\text { method } \\
\text { Recovery\% }\end{array}$} \\
\cline { 2 - 5 } & Recovery\%* & $\begin{array}{c}\text { RSD } \\
\% *\end{array}$ & Recovery\%* & $\begin{array}{c}\text { RSD } \\
\% *\end{array}$ & FIA method \\
\hline $\begin{array}{c}\text { Breath } \\
\text { Rx }\end{array}$ & 100.31 & 0.123 & 99.18 & 0.390 & 98.48 \\
\hline Listarine & 101.18 & 1.187 & 99.87 & 0.960 & 100.86 \\
\hline
\end{tabular}

* for four determinations
Since F-test and T-test showed that there was no significant difference between the proposed batch method and the official method using 4aminoantipyrine (4-AAP) and potassium ferricyanide (Table 3 ).

Table (3): The comparison of the proposed batch method with standard method using $t$ - and Fstatistical tests

\begin{tabular}{|c|c|c|c|c|}
\hline \multirow{2}{*}{$\begin{array}{l}\text { The pharmaceutical } \\
\text { preparations for } 2.0 \\
\mu \mathrm{g} \cdot \mathrm{ml}^{-1}\end{array}$} & \multicolumn{2}{|c|}{ The proposed method } & \multicolumn{2}{|c|}{ The official method } \\
\hline & Rec. $\%$ & $\left(\mathrm{Xi}^{-} \mathrm{Xi}^{-}\right)^{2}{ }_{1}$ & Rec.\% & $\left(\mathrm{Xi}-\mathrm{X}^{-}\right)^{2}{ }_{2}$ \\
\hline Pure thymol & 99.68 & 0.592 & 98.00 & 2.073 \\
\hline Breath Rx & 100.31 & 0.019 & 99.48 & 0.001 \\
\hline \multirow[b]{2}{*}{ Listarine } & 101.18 & 0.532 & 100.86 & 2.016 \\
\hline & $\begin{array}{l}\left(\mathrm{Xi}^{-}\right)_{1}= \\
100.45\end{array}$ & $\begin{array}{c}\sum_{\mathrm{Xi}^{-}} \mathrm{Xi}_{1}{ }_{1}= \\
1.143\end{array}$ & $\begin{array}{c}\left(\mathrm{Xi}^{-}\right)_{2}= \\
99.44\end{array}$ & $\begin{array}{c}\sum_{(\mathrm{Xi}-}\left(\mathrm{X}^{-}\right. \\
\left.\mathrm{Xi}^{-}\right)_{2}^{2}= \\
4.090\end{array}$ \\
\hline \multicolumn{5}{|c|}{$\mathrm{F}_{\text {calculated }}=\mathrm{S}_{1}^{2} / \mathrm{S}_{2}^{2}=0.571 / 2.045=0.279$} \\
\hline \multicolumn{5}{|c|}{$\begin{array}{l}\mathrm{F}_{\text {theoretical }}=19.0, \quad \mathrm{~F}_{\text {theoretical }}>\mathrm{F}_{\text {calculated }} \\
\text { at } 95 \% \text { confidence level, }\end{array}$} \\
\hline
\end{tabular}

\section{Conclusion:}

Although very few methods are available for the determination of Thymol by spectrophotometric analysis. The suggested methods, which are simple and rapid offer the advantages of sensitivity more than all reported methods [3-16], which needed either temperature or solvent extractions, expensive materials and reagents. The important advantage of this work was on using the drug procaine hydrochloride (local anesthetic) as a new coupling reagent instead of other organic amino reagents which were poisioneous and expensive. In addition, the wide applicability of the new method for routine quality control is well established by analyzing the assay of Thymol at concentration of trace level (ppm) in mouth wash formulations.

\section{References:}

1. "British Pharmacopoeia", 2007, the Stationery Office on behalf of the Medicines and Healthcare products Regulatory Agency (MHRA). London, $5^{\text {th. }}$ ed. 
2. "The British Pharmaceutical Codex", 1911, the Council of the Pharmaceutical Society of Great Britain. London, $1^{\text {st. }}$ ed.

3. Thompson RD and Carlson M, 1989, "Determination of Thymol in halothane anaesthetic preparations by high-performance liquid chromatography", J. Pharm. Biomed. Anal., 7 (10),1199-1206.

4. Ji L, Wang YY, Tong Y, Li XD, Feng XF, Hang, LQ and Zhou, GP, 2004, "Determination of carvacrol and Thymol in Mosla chinensis by HPLC" Zhongguo Zhong Yao Za Zhi, 29: 1030-2.

5. Kang LI, Jinsong YUAN and Weiwei SU, 2006, "Determination of Liquiritin, Naringin, Hesperidin, Thymol, Imperatorin, Honokiol, Isoimperatorin, and Magnolol in the Traditional Chinese Medicinal Preparation Huoxiang-zhengqi Liquid Using High-performance Liquid Chromatography", Yakugaku Zasshi, 126 (11), 1185-1190.

6. Gao H, Cao W, Liang Y, Cheng N, Wang B and Zheng J, 2010, "Determination of Thymol and Phenol in Honey by LC with Electrochemical Detection", Chromatographia, 72 (3-4), 316363.

7. Noall MW, Knight V, Hargrove WW and Elledge BW, 1975, "Gas chromatographic determination of Thymol", Anal. Biochem., 69 (1), 10-15.

8. Kohlert C, Abel G, Schmid E and Veit M, 2002, "Determination of Thymol in human plasma by automated headspace solid-phase microextraction-gas

chromatographic analysis", J Chromatogr B Analyt Technol Biomed Life Sci., 767(1),11-8.

9. Tsigouri A, Passaloglou-Katrali M and Sabatakou O, 2008,
"Determination of eucalyptol camphor menthol and Thymol in Greek thyme honey by GC-FID", Greek thyme honey by GC-FID", Acta Alimentaria, 37 (2), 181-189.

10. Badertscher $R$, Kilchenmann $V$, Liniger A and Gallmann P, 2010, "Determination of 1,4dichlorobenzene, naphthalene and Thymol residues in honey using static headspace coupled with GCMS", J. ApiProduct \& ApiMedical Sci., 2 (3), 78-92.

11. Lau OW, Luk SF and Wong WC, 1988 , "Simultaneous determination of methyl salicylate and Thymol in various pharmaceutical formulations by differential-pulse voltammetry using a glassy carbon electrode", Analyst,113, 865-868.

12. Korany MA, Seif El-Din AA and Abdel-Salam NN, 1984, "Application of second derivative ultraviolet spectrometry Part III : Determination of eugenol, Thymol and anethole in volatile oils", Anal. Lett., 17(A6), 483.

13. Fibranz L, Blake $\mathrm{MI}$ and Miller CE, 1985, "Colorimetric determination of Thymol in thyme oil" J. Am. Pharm. Asso., 47 (2), 133-135.

14. Morrison RT and Boyed RN, 1973, "Organic Chemistry", $3^{\text {rd }}$ .ed., Allyn and Bucon, Inc., Bosten, 451.

15. Al-Abachi MQ, Al-Delami AMS and Al-Najafi AS, 1988, "Spectrophotometric

determination of 4aminoantipyrine in aqueous solution by coupling with diazotized 4-nitroaniline", Analyst, 113, 1661.

16. Al-Abachi MQ and Al-Gabsha TS, 1983, "Fundamentals of analytical chemistry", Press of Mousl university. 343 and 346. 
17. Rodriguez LA and Romero JE, 1999, "Flow injection spectrophotometric determination of phenolic drugs and carbamate pesticides by coupling with diazotized 2,4,6-trimethylaniline", J. Assoc. Off. Anal. Chem, 82 (4), 937-947.

18. Calatayud JM., 2003, "Flow Injection Analysis of

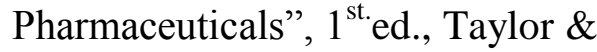
Francis Inc., USA., 26.

19. Bigley FP and Grob RL, 1985, "Determination of phenols in water and wastewater by post-column reaction detection high-performance liquid chromatography", J. Chromatogr, 350, 407-416.

\section{التقدير الطيفي للثايمول بوساطة طريقتي الدفعة والحقن الجرياني باستخدام هيدركلورايد البروكائين ككاشف لوني لوفي وليد}

هند صادق الوردث*

\author{
مؤيل قاسم العباجي* \\ *ققم الكيمياء-كلية العلوم -جامعة بغداد-بغداد_العراق
}

يتضمن البحث تطوير طريقتن طيفيتنين جديدة وبسيطة للتقدير الكمي لمقادير ضئيلة من الثايمول في

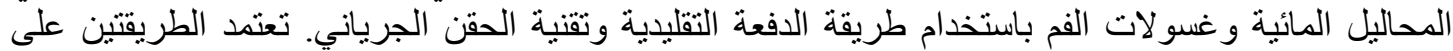

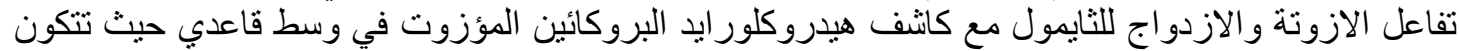

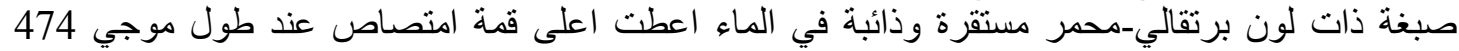

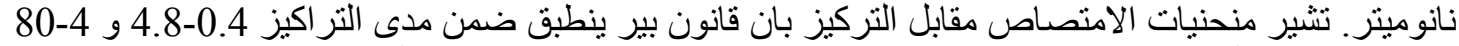

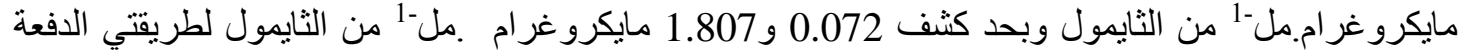

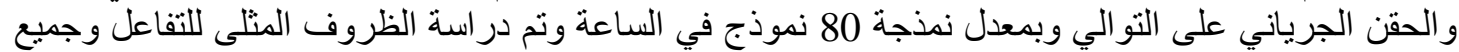

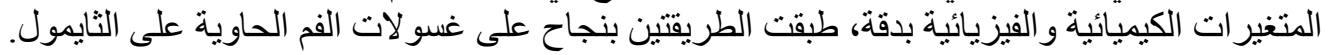

